\title{
Psychometric Study of the Scale of Interests by Areas of Psychology - Portuguese Version
}

\author{
Rodolfo Augusto Matteo Ambiel ${ }^{1}$ (D) \\ Gustavo Henrique Martins ${ }^{1}$ (I) \\ Maria do Céu Taveira ${ }^{2}$ \\ Ana Carolina Zuanazzi \\ Jucimara Zacarias Martins ${ }^{1}$ (D) \\ Airton Antonio Cicchetto ${ }^{1}$
}

\begin{abstract}
Considering the need to understand the variables related to the choice for Psychology specialties, this study aimed to present the adaptation process and to verify validity evidence based on the internal structure for the Portuguese version of the Scale of Interests by Areas of Psychology (EIAPsi) and relate it to personality. The sample consisted of 340 Portuguese university students, using the EIAPsi and the NEO Five-Factor Inventory (NEO-FFI). Exploratory Factor Analysis and correlations between instruments were performed. There was a factorial structure formed by 10 factors for the EIAPsi with satisfactory precision indexes. The dimensions of openness and agreeableness were the most frequently correlated to the areas of Psychology. We have concluded that evidence of initial validity of the instrument were presented, indicating possibilities of its use in the Portuguese context, specifically in situations aimed at self-knowledge (classroom or clinic/office) and guiding students in choosing their area of expertise.
\end{abstract}

Keywords: professional interests, vocational guidance, psychology, higher education, personality traits

\section{Estudo Psicométrico da Escala de Interesses por Áreas da Psicologia - Versão Portuguesa}

\begin{abstract}
Resumo: Ao considerar a necessidade de compreensão das variáveis relacionadas à escolha por especialidades da Psicologia, este estudo teve por objetivo apresentar o processo de adaptação e verificar evidências de validade baseadas na estrutura interna para a versão portuguesa da Escala de Interesses por Áreas da Psicologia (EIAPsi) e relacioná-la com personalidade. A amostra foi composta por 340 universitários portugueses, utilizando a EIAPsi e o NEO Five-Factor Inventory (NEO-FFI). Foram realizadas Análise Fatorial Exploratória e correlações entre instrumentos. Verificou-se uma estrutura fatorial formada por 10 fatores para a EIAPsi com satisfatórios índices de precisão. As dimensões abertura e amabilidade foram as mais frequentemente correlacionadas às áreas da Psicologia. Conclui-se que evidências de validade iniciais do instrumento foram apresentadas, indicando possibilidades de sua utilização no contexto português, especificamente em situações que visem o autoconhecimento (sala de aula ou clínica/ consultório) e direcionamento dos estudantes para escolha da área de atuação.
\end{abstract}

Palavras-chave: interesses profissionais, orientação vocacional, psicologia, ensino superior, traços de personalidade

\section{Estudio Psicométrico de la Escala de Intereses en Áreas de la Psicología - Versión Portuguesa}

\begin{abstract}
Resumen: Considerando la necesidad de comprender las variables relacionadas con la elección de las especialidades en Psicología, este estudio tuvo como objetivo presentar el proceso de adaptación y verificar las evidencias de validez basadas en la estructura interna de la versión portuguesa de la Escala de Intereses en Áreas de la Psicología (EIAPsi) y relacionarla con la personalidad. La muestra constó de 340 estudiantes universitarios portugueses, a la cual se aplicó la EIAPsi y el NEO Five-Factor Inventory (NEO-FFI). Se llevaron a cabo un análisis factorial exploratorio y correlaciones entre los instrumentos. Se observó una estructura factorial formada por 10 factores para la EIAPsi con índices de precisión satisfactorios. Las dimensiones apertura y amabilidad fueron las que más se correlacionaron con las áreas de la Psicología. Se concluye que el instrumento presentó evidencias iniciales de validez, lo que indica su potencial de uso en el contexto portugués, sobre todo en situaciones dirigidas al autoconocimiento (aula o clínica/oficina) y el soporte a los estudiantes en la elección del área de actuación.
\end{abstract}

Palabras clave: intereses profesionales, orientación vocacional, psicología, educación superior, rasgos de personalidad

\section{${ }^{1}$ Universidade São Francisco, Campinas-SP, Brazil \\ ${ }^{2}$ Universidade do Minho, Braga-Portugal}

Support: National Council for Scientific and Technological Development (Conselho Nacional de Desenvolvimento Científico e Tecnológico - CNPq; 138943/2015-0) e Coordination for the Improvement of Higher Education Personnel (Coordenação de Aperfeiçoamento de Pessoal de Nível Superior CAPES; finance code 001)

Correspondence address: Rodolfo Augusto Matteo Ambiel. Universidade São Francisco. Rua Waldemar César da Silveira, 105, Jardim Cura D'ars, Campinas-SP, Brazil. CEP 13.045-510. E-mail: ambielram@gmail.com
Professional interests have been studied since the mid-twentieth century, with John Holland (1997) as one of the main representatives in the subject. From Holland's perspective, professional interests can be understood as an expression of the personality traits in the world of work. Therefore, the author developed a typological model to explain the professional choice, based on six personality characteristics (Lamas, 2017). This model is known as RIASEC, an acronym for the types of vocational personality 
Realistic, Investigative, Artistic, Social, Enterprising and Conventional (Holland, 1997).

After this, the professional interests have been defined by Lent, Brown and Hackett (1994) as patterns of affinity, indifference or aversion, related to professional activities. According to these same authors, interests are formed by beliefs in capacities and expectations of results from certain actions by the individual, which are reassessed every time the subject goes through a new experience. Still in this perspective, Rounds and $\mathrm{Su}$ (2014) consider that professional interests can be understood as preferences for activities and contexts, and that they can also motivate the achievement of goals, besides being an important predictor of performance and success.

A meta-analysis study carried out by Low and Rounds (2007), found out that professional interests are relatively stable during someone's lifetime, even more stable than the individuals' own personality. The years of strong growth in the stability of interests occur in the beginning of adulthood (18 to 22 years old), which corresponds to the moment when the young person enters university and the labor market, thus restricting the environments, which ends up limiting the formation of new interests.

There are different ways of assessing the professional interests, with two main classifications in this regard, the assessment of the expressed and inventoried interests. The first ones are assessed through an individual's responses to open-ended questions about which professions interest him or her most. But the inventoried/tested interests are measured through the person's scores in the psychometric tests to assess global interests, which are likely to remain relatively stable over time and to better agree with the professional choice itself (Lamas, 2017).

In this sense, some researches have been committed to the assessment of inventoried interests through general samples, often neglecting the importance of also evaluating interests in specific domains, as in the case of Psychology, in which students present different interests between possible areas of action. About this, some studies have assessed the general interests of Psychology students (Bueno, Lemos, \& Tomé, 2004; Espírito \& Castro, 2012; Magalhães, Straliotto, Keller, \& Gomes, 2001), indicating interest and need for study of this population.

One of the reasons for conducting investigations on Psychology students may be due to the diversity of areas of activity that the course presents, which requires the student and/or professional to have a very broad contact with information, theoretical lines and methods, with the need for choices as well as continuing education, which begin during graduation. In this sense, the curricular grids of undergraduate courses in Psychology seek to include various specialties in the training, which requires the students and professionals to choose areas, for a continuous investment in view of the individual, educational and/or social demands (Bedin, Sarriera, \& Paradiso, 2013).

To contextualize Psychology in Portugal, the training of the first psychologists took place in the early 1980 s, and the Portuguese Psychologists Order (OPP) was created in 2008, through the Decree-Law No. 57/2008 (Mendes, AbreuLima, \& Almeida, 2015). In April 2015, there were 20.643 psychologists enrolled in the OPP (2015).

In Decree-Law No. 42 (2005), in coherence with the commitments resulting from the Bologna Declaration (signed by the country with 29 other European countries on June 19, 1999), regulatory standards for Portuguese higher education courses were instituted, among which: the structure of three cycles (Bachelor's, Master's and $\mathrm{PhD}$ degrees) and the creation of a new system of curricular credits. Thus, in accordance with the country's legislation, in order to practice the profession, in Portugal, training in Psychology must include at least two study cycles, being three years at the undergraduate level plus two years at the Master's level. The third cycle (optional) refers to the Doctor's level. The performance of the profession also requires the accomplishment and approval in a professional internship of one year, in one of three possible areas: clinical and health psychology, educational psychology, and psychology of work, organizations and society. Universities have progressively been integrating these same areas in the curricula of the second and third cycles of higher education in Psychology. In addition, the process of professional specialties was put into practice by the OPP in 2016, recognizing and certifying the training and qualification of psychologists for the professional practice as specialists in one of those areas of Psychology (European Federation of Psychologists' Association [EFPA], 2018; OPP, 2016).

Rodrigues, Ferreira and Bártolo-Ribeiro (2013) have developed the Psychology Interest Scale in Portugal, which assesses the professional interests of Psychology students. The sample in the study was of 573 students from nine public and private higher education institutions. After Principal Component Analysis, the authors found the structure composed of 21 items as the best structure for the scale, divided equally into three areas of activity: Clinical, Educational and Organizational.

Two years later, a study with the same scale was published to verify the relationship of these interests by areas of Psychology with the RIASEC model (Ferreira, Rodrigues, $\&$ Ferreira, 2015). For this, these authors surveyed a sample of 304 Psychology students of the first three years of the undergraduate course. Positive and significant correlations were observed between interests in the Clinical and Educational areas and the Social type of the RIASEC model. The interests in the Organizational area showed a positive and significant correlation with the Enterprising type.

Another scale, also in Portuguese, which assesses professional interests in the different activity areas and possibilities in Psychology, was developed in Brazil by Ambiel and Martins (2016), and called the Scale of Interests by Psychology Areas (EIAPsi). The authors had the participation of 392 Brazilian Psychology students. The results showed that the scale evaluation correctly discriminated the expressed interests of people. In addition, good accuracy indexes were reported for the 11 factors of the scale, with alpha values higher than 0.84 obtained in all 
factors. However, there are still no psychometric studies with EIAPsi in Portuguese samples, nor evidence of validity based on the relationship with other variables.

As previously indicated, Holland (1963) highlights that the individual's personality is expressed in work activities. Furthermore, Savickas (1995) points out that interests are a form of expressing personality, considering that they can perform an intermediation between the individual and the world of work. This relationship was verified in the study by Shimada, Melo-Silva and Taveira (2016). In turn, the meta-analysis carried out by Hurtado Rúa, Stead and Poklar (2019), indicated that the Big Five dimensions most related to RIASEC's interests were Opening and Extroversion. In view of this issue, it becomes necessary to discuss the interface between professional interests, personality and areas of Psychology, considering the need to understand the existing variables and the possibility of offering training that can manage the demands that arise during the process, due to the choice among the specialties of Psychology.

Few studies have set out to investigate these constructs in the context of Psychology, most of which are aimed at the general population, only analyzing possible differences according to schooling (Pedroso-Lima et al., 2014). Bueno et al. (2004), in turn, found that there was a tendency, among new students of the Psychology course, to contest the norms, openness to experience, extroversion and low tolerance to frustration, in addition to a greater interest in social activities as opposed to activities related to calculation.

Associated with this, the psychologist's stereotype still relates to the professional who works mostly in the clinical, educational and organizational contexts (Magalhães et al., 2001; Yamamoto \& Costa, 2010). Considering the requirements for the training of psychologists, whether in the Portuguese or international context, with specific skills and competences, ethical principles and contextualization with the socio-cultural aspect, a wide number of possibilities for the performance of this professional has been generated. It becomes useful to develop instruments that assess, with good psychometric characteristics, the interests in specific areas in Psychology, aiming to offer a complementary tool to assist the process of choice in the areas (Campos, Catão, \& Fujii, 1999), an objective proposed by the EIAPsi (Ambiel \& Martins, 2016, 2019).

In this sense, the objective of this study was to present the adaptation process and verify evidence of validity based on the internal structure for the Portuguese version of the EIAPsi. Moreover, in view of the strong relationship between personality characteristics and professional interests, we sought to analyze, in an exploratory way, the association between personality traits in the Big Five model and areas of interest assessed by the scale.

We expect to find a factorial structure of EIAPsi similar to the one found in the Brazilian version, formed by 11 factors/ areas of Psychology (Ambiel \& Martins, 2016, 2019); as well as positive correlations between personality traits Openness, Extroversion, Conscientiousness and Agreeableness and areas of interest measured by EIAPsi (Ambiel, Noronha, \&
Nunes, 2012; Bueno et al., 2004; Bullock \& Reardon, 2008; Hurtado Rúa et al., 2019; Wille \& De Fruyt, 2014); finally, the Neuroticism personality trait is expected to correlate negatively with the areas of interest measured by the EIAPsi (Bueno et al., 2004; Bullock \& Reardon, 2008; Hurtado Rúa et al., 2019; Wille \& De Fruyt, 2014).

\section{Method}

\section{Participants}

This study was conducted using a convenience sample, in which 340 Portuguese Psychology students participated, mostly female $(85 \%)$, from public $(80.9 \%)$ and private $(19.1 \%)$ universities. The participants' ages ranged from 18 to 53 years $(M=20.99, D P=4.42)$. There were participants attending the $1 \mathrm{st}(31.2 \%)$, 2nd $(33.2 \%)$, 3rd $(12.1 \%)$ undergraduate years and the $1 \mathrm{st}(23.5 \%)$ year of the Master's program. There was an attempt to collect data from students of the 2nd year of the Master's program. However, since they were doing their mandatory internships outside the place where the survey was being carried out, it became unfeasible.

\section{Instruments}

Sociodemographic Questionnaire. It was designed for this study. It sought to assess the sociodemographic and academic characteristics of the participants, by asking questions about sex, age, type of institution and year of schooling.

Scale of Interests by Areas of Psychology - Portuguese version (EIAPsi-PT; Ambiel, Martins, \& Taveira, 2020). EIAPsi assesses the interests of Psychology students and professionals, regarding the different areas of the profession. The 90 items of the Brazilian version were adapted, answered on a Likert scale with five points, ranging from "I hate/would hate to perform this activity (1)" to "I love/ would love to perform this activity (5)". The Brazilian version of the EIAPsi is composed of 11 factors, which are: Clinical $(M=3.94 ; S D=0.71 ; \alpha=0.83)$, Health $(M=3.56$; $S D=0.86 ; \alpha=0.89)$, Educational $(M=3.38 ; S D=0.86$; $\alpha=0.91)$, Organizational $(M=3.19 ; S D=1.00 ; \alpha=0.95)$, Social $(M=3.53 ; S D=0.79 ; \alpha=0.89)$, Psychological Assessment $(M=3.57 ; S D=0.77 ; \alpha=0.87)$, Teaching and Research $(M=3.18 ; S D=0.88 ; \alpha=0.92)$, Traffic $(M=2.80$; $S D=1.04 ; \alpha=0.89)$, Sports $(M=2.80 ; S D=0.97 ; \alpha=0.93)$, Legal $(M=3.25 ; S D=0.95 ; \alpha=0.90)$ and Neuropsychology $(M=3.48 ; S D=0.92 ; \alpha=0.88)$ (Ambiel \& Martins, 2019).

Initially, the content of the 90 items of the Brazilian EIAPsi version was revised by a Psychology Ph.D. and a specialist in the field, to adapt the scale to the Portuguese context. A total of 20 items had some kind of change related to their writing/semantics. The biggest changes were registered in the items "doing a teaching internship", changed to "qualify for university training or education", "participate in multiprofessional teams in the planning and implementation of traffic safety policies", which was 
changed to "participate in multiprofessional teams focused on planning and implementing traffic policies", and "giving feedback from evaluations", which was changed to "communicating evaluation results". The other items had just one word changed. Some examples of these changes are the words: detainees, sports, teams, doctorate, dismissal, planning. It is worth to mention that all the changes made were carefully thought out, so that the characterization of the professional activity that the item represented was not lost.

After adapting the items, the scale went through a process of spoken reflection, to assess the understanding of the items, as well as the response process to the instrument. The evaluation of the understanding regarding the items was carried out independently, by two Portuguese students of the 1st year of the master's program in Psychology. In two items, a need to change was identified, to make them more understandable. So the item "working in NGOs guaranteeing psychological support to its members" was changed to "working in Non-Governmental Organizations (NGOs) guaranteeing psychological support to its recipients" and the item "developing and implementing professional skills training" had the writing changed to "planning and executing professional skills training sessions". The response to the instrument occurred satisfactorily by both students, suggesting the possibility to start the empirical collection.

NEO Five-Factor Inventory - NEO-FFI (Lima \& Simões, 2000; Magalhães et al., 2014). This instrument, which has adaptations in different languages and cultures and is available for use in Portugal, was conceived to be a brief measure for personality assessment through the Big Five model. It consists of 60 items, equally divided into five personality dimensions, namely Neuroticism (e.g., I often feel inferior to other people), Extroversion (e.g., I like having a lot of people around me), Agreeableness (e.g., I try to be gentle with all the people I meet), Openness to experience (e.g., I am in awe of the models I find in art and nature) and Conscientiousness (e.g., I keep my things clean and in order). The answer key is given on a Likert scale that ranges from "strongly disagree (0)" to "strongly agree (4)". The adaptation study for the Portuguese version indicated satisfactory internal consistency indexes, with alpha coefficients ranging from 0.71 (Openness) to 0.81 (Neuroticism and Conscientiousness)

\section{Procedure}

Data collection. The empirical collection was carried out in person, in paper and pencil format, in a classroom with an average of 40 students for each application and an approximate duration of 30 minutes, after the approval of the professor responsible for the discipline and the participants' informed consent. The instruments were applied in the following order: Identification questionnaire, EIAPsi and NEO-FFI. Participants were instructed to respond attentively and following the order of presentation of the instruments.

Data analysis. The data were tabulated and analyzed with the software SPSS 25, Factor Analysis 10.8.04 and Mplus 7. Initially, the methods, Parallel Analysis, Hull and Minimum Average Partial (MAP) were used to guide decision making on the number of factors to be extracted. The possibility of the data set being fitted to a factorial model was verified by the Kaiser-Meyer-Olkin index (KMO). Then an Exploratory Factor Analysis was performed, with WLSMV estimator and Geomin rotation of the Portuguese version of the EIAPsi. Thus, only items with factorial loads equal to or greater than 0.35 were maintained, this value being adopted to minimize possible confusion in the maintenance of items, thus avoiding the permanence of items with loads too close to the acceptable minimum (0.30; Pasquali, 2003). To interpret the model's adjustment indexes, the following values indicated by Hu and Bentler (1999) will be used: chi-square ratio for degrees of freedom $\left(\mathrm{X}^{2} / \mathrm{gl}<3\right)$, Confirmatory Fit Index (CFI > 0.95), Tucker-Lewis Index (TLI $>0.95)$, Root Mean Square Error of Approximation (RMSEA $<0.05$ ) and Standardized Root Mean Square Residual (SRMR < 0.08). The precision of the factors was verified using alpha and omega coefficients. Finally, Pearson correlations between EIAPsi and NEO-FFI factors were calculated.

\section{Ethical Considerations}

The project was submitted and approved by the Research Ethics Committee (Opinion No.: 770.173, No. CAAE: 34976414.4.0000.5514). The students were informed about the research objectives and, after signing the Free and Informed Consent Form, they responded to the instruments.

\section{Results}

The KMO index of 0.90 indicated the factorability of the data set formed by the 90 items of the Portuguese version of the EIAPsi. Then the Hull method indicated one factor, the MAP indicated six factors and the Parallel Analysis indicated nine factors as the best factor structure. However, as the items were constructed to represent professional activities in 11 areas of Psychology, this one was adopted as a factorial structure to be tested in the Exploratory Factor Analysis. When analyzing the content of the items that grouped in each factor, it was seen that despite the good adjustment indexes for the model $\left(\mathrm{X}^{2} / \mathrm{gl}=1.38 ; \mathrm{CFI}=0.96 ; \mathrm{TLI}=0.95 ; \mathrm{RMSEA}=0.03\right.$; SRMR $=0.03$ ), the solution was poorly interpretable in terms of grouping the items. For this reason, we chose the structure formed with 10 factors for the analysis execution.

When analyzing the content of the items for each factor, we noticed that three items presented factorial loads in areas not consistent with their respective theoretical contents. For this reason, we decided to exclude these three items. They are: the item "collaborate in the integration of workers with new equipment or work teams" with a load of 0.38 (Teaching and Research), the item "assist in the assessment and guidance in conciliation hearings" with a load of 0.46 (Clinic and Health) and the item "plan and execute professional skills training sessions" with loads of 0.43 
(Sports) and 0.36 (Organizational). In addition to these, two more items were excluded due to factorial loads of less than 0.35 ("acting in the understanding of the social construction of the subjectivity of the subjects" and "writing documents reporting results of assessment procedures").

After this, the Exploratory Factor Analysis was performed again with the remaining 85 items. The ten- factor structure explained $66 \%$ of the variance. The model's adjustment indexes were good $\left(\mathrm{X}^{2} / \mathrm{gl}=1.44\right.$; $\mathrm{CFI}=0.96$; $\mathrm{TLI}=0.94 ; \mathrm{RMSEA}=0.04 ; \mathrm{SRMR}=0.03$ ), indicating that this is an adequate model for representing that sample's data. No item was excluded because it had a factor load lower than 0.35 . The factorial loads of the items and the factor that each item represents will be described in Table 1 .

Table 1

Grouping of items in the factors of the EIAPsi-Portugal

\begin{tabular}{|c|c|c|}
\hline Items & Loads & Factors \\
\hline 25 Work with hospitalized terminal patients & 0.86 & Clinic and Health \\
\hline 7 Carry out psychotherapeutic consultations in private offices or clinics & 0.84 & Clinic and Health \\
\hline 10 Assist families with terminally ill patients, assisting in the acceptance process & 0.82 & Clinic and Health \\
\hline 74 Assist the patient, his or her family and the health team. in a health unit & 0.82 & Clinic and Health \\
\hline 45 Give assistance to people who have gone through a major disaster & 0.78 & Clinic and Health \\
\hline 28 Assist people who had some type of accident & 0.74 & Clinic and Health \\
\hline $\begin{array}{l}81 \text { Work in health centers and services in the community, hospitals, psychiatric clinics or } \\
\text { mental health care }\end{array}$ & 0.74 & Clinic and Health \\
\hline 23 Promote psychosocial rehabilitation of individuals with depression & 0.72 & Clinic and Health \\
\hline 33 Carry out psychotherapeutic care with individuals, couples, families and groups & 0.72 & Clinic and Health \\
\hline 67 Assist in preparing patients for entry, stay and discharge from hospital & 0.70 & Clinic and Health \\
\hline 57 Work for public health devices & 0.60 & Clinic and Health \\
\hline 40 Intervene in the psychological phenomena of the individual & 0.50 & Clinic and Health \\
\hline 51 Assist patients/clients based on a specific theoretical approach & 0.36 & Clinic and Health \\
\hline 27 Supervise other clinical psychologists & 0.35 & Clinic and Health \\
\hline 39 Give assistance to prepare an athlete for the performance of the activity & 0.93 & Sports \\
\hline $\begin{array}{l}35 \text { Collaborate for the understanding and transformation of inter and intrapersonal } \\
\text { relationships in sporting environments }\end{array}$ & 0.90 & Sports \\
\hline 46 Apply instruments to determine individual and collective profile for the practice of sports & 0.86 & Sports \\
\hline 60 Help athletes, coaches and technical commissions to achieve an optimal level of mental health & 0.85 & Sports \\
\hline $\begin{array}{l}84 \text { Develop actions to improve individual psychic abilities with a view to optimizing the } \\
\text { performance of high competion athletes }\end{array}$ & 0.81 & Sports \\
\hline $\begin{array}{l}70 \text { Collaborate for the adhesion and participation of the general population in physical } \\
\text { activity programs }\end{array}$ & 0.71 & Sports \\
\hline 21 Help the population to participate in physical activities & 0.51 & Sports \\
\hline $\begin{array}{l}30 \text { Guide parents or guardians about the choice of sport and the implications for the child's } \\
\text { development cycle }\end{array}$ & $0.56 / 0.46$ & Sports/Educational \\
\hline 13 Write scientific reports and papers & 0.85 & Teaching \\
\hline 49 Advise the work of undergraduate, master's and doctoral students & 0.81 & Teaching \\
\hline 1 Publish scientific articles & 0.78 & Teaching \\
\hline 36 Develop research problems and hypotheses & 0.78 & Teaching \\
\hline 73 Give opinions about manuscripts to scientific journals of the area & 0.78 & Teaching \\
\hline 65 Participate in the case for a master's and doctoral degree & 0.67 & Teaching \\
\hline 6 Propose innovative research projects to answer questions in psychology & 0.62 & Teaching \\
\hline 44 Communicate evaluation results & 0.61 & Teaching \\
\hline 26 Constantly updating in relation to scientific literature & 0.59 & Teaching \\
\hline 85 Perform data collections using different techniques & 0.58 & Teaching \\
\hline 56 Perform statistical analyses & 0.51 & Teaching \\
\hline 43 Teaching classes on specific contents & $0.81 / 0.50$ & Teaching/Educational \\
\hline 31 Get trained to be a university professor & $0.63 / 0.44$ & Teaching/Educational \\
\hline 8 Assist in teaching-learning processes & 0.87 & Educational \\
\hline 75 Analyze and intervene in the educational climate & 0.85 & Educational \\
\hline 22 Facilitate the development and integration of students in the school context & 0.79 & Educational \\
\hline 79 Work preventively in daycare centers and schools & 0.72 & Educational \\
\hline 19 Work on family-community-school integration & 0.70 & Educational \\
\hline
\end{tabular}

Continued... 
Table 1

Continuation

\begin{tabular}{|c|c|c|}
\hline Items & Loads & Factors \\
\hline 38 Analyze the different segments of the educational system & 0.70 & Educational \\
\hline $\begin{array}{l}41 \text { Assess the efficiency of educational programs based on psychological tests and appropriate } \\
\text { instruments }\end{array}$ & 0.61 & Educational \\
\hline 55 Guide the application of specific teaching programs for individuals with special needs & 0.56 & Educational \\
\hline 58 Working with children with difficulties and / or delays in global development & 0.51 & Educational \\
\hline 14 Assessing detainees who are on probation & 0.89 & Legal \\
\hline 3 Work with individuals in situations of legal proceedings & 0.86 & Legal \\
\hline 5 Prepare reports on the mental functioning of individuals in legal proceedings & 0.76 & Legal \\
\hline 9 Collaborate in the formulation of criminal policies & 0.72 & Legal \\
\hline 24 Promote activities that detainees can carry out in penal establishments & 0.70 & Legal \\
\hline 18 Acting on psychological support for the families of detainees & $0.63 / 0.41$ & Legal/Clinic and Health \\
\hline 52 Engage in research that expands psychological knowledge applied to law & $0.47 / 0.38$ & Legal/Teaching \\
\hline 54 Perform assessment of neuropsychological functions & 0.85 & Neuropsychology \\
\hline 4 Understand the relationship between brain functioning and behavior & 0.83 & Neuropsychology \\
\hline 47 Develop a treatment plan for the patient's neuropsychological rehabilitation & 0.73 & Neuropsychology \\
\hline 17 Assist in deciding on medical treatment for neurological patients & 0.70 & Neuropsychology \\
\hline $\begin{array}{l}11 \text { Develop games and activities for assessment, prevention and neuropsychological } \\
\text { rehabilitation }\end{array}$ & 0.56 & Neuropsychology \\
\hline 64 Perform clinical research work, using neuropsychological tests and exercises & $0.50 / 0.38$ & Neuropsychology/Teaching \\
\hline 71 Work with the relationships between subjects in the work environment & 0.83 & Organizacional \\
\hline $\begin{array}{l}76 \text { Facilitate the relationship between people and organizations, contributing to the } \\
\text { development of both }\end{array}$ & 0.81 & Organizacional \\
\hline 50 Take responsibility for improving working conditions in the organization & 0.80 & Organizacional \\
\hline 68 Understand the subjective meaning attributed by employees to the work performed & 0.77 & Organizacional \\
\hline 37 Work in companies & 0.76 & Organizacional \\
\hline 82 Select employees for a new job & 0.73 & Organizacional \\
\hline 29 Assist employee welfare & 0.69 & Organizacional \\
\hline 16 Intervene in conflict situations between employees & 0.68 & Organizacional \\
\hline 59 Participate in the dismissal process of company employees & 0.66 & Organizacional \\
\hline $\begin{array}{l}83 \text { Identify the social representations that mediate individuals' relationships with their } \\
\text { environments }\end{array}$ & 0.44 & Organizacional \\
\hline 42 Advising NGOs and working cooperatives & $0.58 / 0.55$ & Organizacional/Social \\
\hline 77 Enable decision-making based on evaluations & $0.48 / 0.42$ & $\begin{array}{l}\text { Organizacional/ } \\
\text { Psychodiagnosis }\end{array}$ \\
\hline 78 Privileging group processes in assessments and interventions & $0.43 / 0.40$ & $\begin{array}{l}\text { Organizacional/ } \\
\text { Psychodiagnosis }\end{array}$ \\
\hline 61 Plan evaluation processes in different performance contexts & 0.45 & Psychodiagnosis \\
\hline 15 Conduct evaluations to arrive at a psychodiagnosis & 0.44 & Psychodiagnosis \\
\hline 62 Use various techniques to improve the efficiency of psychotherapeutic practices & 0.42 & Psychodiagnosis \\
\hline 2 Know and apply various psychological tests & 0.40 & Psychodiagnosis \\
\hline 53 Know how to properly select instruments for different assessment situations & 0.37 & Psychodiagnosis \\
\hline 12 Work in NGOs providing psychological support to their recipients & 0.68 & Social \\
\hline 66 Plan, evaluate and execute public policies and community programs & 0.50 & Social \\
\hline 72 Mediate the interventions of multiprofessional teams in community contexts & 0.50 & Social \\
\hline 20 Conducting social and community research & 0.49 & Social \\
\hline 34 Work with vulnerable groups in community centers & $0.51 / 0.44$ & Social/Clinic and Health \\
\hline 80 Design and implement traffic health, education and safety programs & 0.77 & Traffic \\
\hline $\begin{array}{l}32 \text { Participate in multiprofessional teams focused on planning and implementing } \\
\text { trafficpolicies }\end{array}$ & 0.65 & Traffic \\
\hline 69 Assess driver's license candidates' abilities, skills and aptitudes & 0.64 & Traffic \\
\hline $\begin{array}{l}63 \text { Work as an expert in driver's qualification exams, rehabilitation or professional } \\
\text { readaptation }\end{array}$ & 0.62 & Traffic \\
\hline 48 Analyze the different factors involved in traffic accidents & 0.58 & Traffic \\
\hline
\end{tabular}


In Table 1 it is possible to observe that the number of items per factor ranged from five (Traffic) to 16 items (Clinic and Health), with some items being computed in two factors, as is the case, for example, of item "64 - carry out clinical research work, using neuropsychological tests and exercises", representing the factors Neuropsychology and Teaching and Research. The set formed by the remaining 85 items, represented ten areas of Psychology. This factorial structure is similar to the one found in the Brazilian version of EIAPsi, except for the Clinic and Health factor, which in this version was represented in two separate factors. Thus, the factors of EIAPsi Portugal are Clinic and Health, Sports, Education, Teaching and Research, Legal, Neuropsychology, Organizations, Psychodiagnosis, Social and Traffic.

In the sequence we presented descriptive statistics of the variables, besides the correlations between the factors of the EIAPsi and the factors of the NEO-FFI. Next, in Table 2, the mean values, standard deviation and precision of the ten EIAPsi factors and the five NEO-FFI dimensions are presented, as well as the correlations between the constructs.

Table 2

Descriptive and correlations of the variables used

\begin{tabular}{|c|c|c|c|c|c|c|c|c|c|c|c|c|c|c|c|c|}
\hline & $\operatorname{Mean}(D P)$ & 1 & 2 & 3 & 4 & 5 & 6 & 7 & 8 & 9 & 10 & 11 & 12 & 13 & 14 & 15 \\
\hline 1.Legal & $3.61(0.80)$ & 0.86 & & & & & & & & & & & & & & \\
\hline 2.Teaching and Research & $2,88(0.79)$ & 0.17 & 0.92 & & & & & & & & & & & & & \\
\hline 3.Clinic and Health & $3.66(0.68)$ & 0.29 & 0.23 & 0.91 & & & & & & & & & & & & \\
\hline 4.Educational & $3.22(0.76)$ & 0.11 & 0.37 & 0.34 & 0.91 & & & & & & & & & & & \\
\hline 5.Sports & $3.08(0.92)$ & 0.05 & 0.20 & 0.07 & 0.46 & 0.93 & & & & & & & & & & \\
\hline 6.Organizational & $3.12(0.74)$ & 0.06 & $\mathbf{0 . 3 1}$ & 0.10 & 0.39 & 0.47 & 0.92 & & & & & & & & & \\
\hline 7.Neuropsychology & $3.58(0.87)$ & 0.20 & 0.51 & 0.46 & 0.34 & 0.13 & 0.09 & 0.88 & & & & & & & & \\
\hline 8.Social & $3.34(0.71)$ & 0.35 & 0.41 & 0.27 & 0.44 & 0.25 & 0.49 & 0.27 & 0.80 & & & & & & & \\
\hline 9.Psychodiagnosis & $3.55(0.58)$ & 0.26 & 0.52 & 0.45 & 0.36 & 0.14 & 0.35 & 0.45 & 0.38 & 0.77 & & & & & & \\
\hline 10.Traffic & $2.55(0.86)$ & 0.15 & $\mathbf{0 . 3 3}$ & 0.32 & 0.45 & 0.50 & 0.57 & 0.29 & 0.37 & 0.33 & 0.88 & & & & & \\
\hline 11.Neuroticism & $1.93(0.65)$ & 0.09 & -0.07 & 0.14 & 0.03 & -0.05 & -0.11 & -0.01 & 0.02 & -0.12 & 0.01 & 0.84 & & & & \\
\hline 12.Extroversion & $2.60(0.46)$ & 0.07 & 0.07 & 0.02 & 0.10 & 0.16 & 0.12 & 0.07 & 0.08 & 0.13 & 0.01 & -0.45 & 0.75 & & & \\
\hline 13.Openness & $2.46(0.49)$ & 0.14 & 0.42 & 0.09 & 0.14 & 0.04 & 0.10 & $\mathbf{0 . 3 3}$ & 0.31 & 0.22 & -0.04 & -0.02 & 0.15 & 0.68 & & \\
\hline 14.Agreeableness & $2.79(0.45)$ & 0.04 & -0.02 & 0.13 & 0.09 & 0.01 & -0.01 & 0.10 & 0.18 & 0.18 & -0.04 & -0.28 & 0.31 & 0.06 & 0.70 & \\
\hline 15.Conscientiousness & $2.88(0.51)$ & -0.03 & 0.09 & 0.11 & 0.03 & 0.06 & 0.05 & 0.13 & 0.01 & 0.18 & 0.07 & -0.33 & 0.26 & 0.01 & 0.32 & 0.83 \\
\hline
\end{tabular}

Note. Correlations marked in bold are significant for $p<0.05$. Diagonally are the precision of the factors measured by the alpha.

Table 2 shows that the areas Traffic and Teaching and Research scored less by the participants and the Clinic and Health area, in turn, scored higher, followed by Legal, Neuropsychology and Psychodiagnosis. These results indicate a tendency of the sample to present less interest in the areas of Teaching and Traffic while, in turn, to report greater interest in Clinic and Health, which are the most disseminated and characteristic areas of the profession.

Regarding the precision, satisfactory alpha values were found for all factors of the EIAPsi, with a variation in the alpha coefficients from 0.77 (Psychodiagnosis) to 0.93 (Sports). The internal consistency of the EIAPsi factors was also verified through the omega coefficient, which indicated satisfactory values, ranging from 0.77 (Psychodiagnosis) to 0.93 (Sports). Yet in the NEO-FFI dimensions, the alpha coefficients were considered acceptable, since they presented values equal to or above 0.68 .

Analyzing the correlations between the factors of the EIAPsi and NEO-FFI, it may be observed that all dimensions of personality correlated significantly with at least one area of interest in Psychology. Most of the significant correlations were weak. It could be observed, for example, the negative correlation between Neuroticism and interests in the Organizational area, as well as the positive correlation between Openness and interests in the area of
Psychodiagnosis. Noteworthy are the positive and moderate strength correlations that had the Openness dimension as a common factor. This personality dimension was the one with the highest number of significant correlations with the areas of interest of the EIAPsi (total of six). Among these correlations, three are of moderate strength, with the areas of Teaching and Research, Neuropsychology and Social.

\section{Discussion}

This study aimed to adapt and verify validity evidence based on the internal structure for the Portuguese version of the EIAPsi. Additionally, the objective was to analyze the association between personality traits and areas of interest assessed by the scale. Therefore, the hypotheses raised for this study were corroborated, partially or totally, since it was possible to find good psychometric properties for the Portuguese version of the EIAPsi, as well as to observe the correlations between personality dimensions and the areas of Psychology measured by the scale.

Based on the 85 items that were included in the Exploratory Factor Analysis, which refer to professional activities performed by psychologists, it was possible to represent ten areas of work in Psychology. This diversity of 
areas assessed is an advance in the assessment of specific interests in Psychology, since other instruments reported did not set out to measure the areas in detail, as occurs by means of the EIAPsi. In the Portuguese context, the existence of a single instrument developed for this purpose was reported, which assesses the interest of Psychology students exclusively through three areas, namely Clinical, Educational and Organizational (Ferreira et al., 2015; Rodrigues et al., 2013), areas also covered by the EIAPsi.

We observed that the first hypothesis of this study was not fully corroborated, because the factorial structure of the Portuguese version of the EIAPsi is formed by ten factors, and not by 11 as was expected (Ambiel \& Martins, 2016, 2019). This difference occurs because the items from the Clinical and Health areas are grouped in a single factor, called Clinic and Health. This result can be better understood from the areas of activity defined by the European Federation of Psychologists' Association (EFPA), which joins the Clinical and Health areas in the same specialty. Moreover, it points to the areas of Clinical and Health Psychology, Educational Psychology and Work and Organizational Psychology, as the three main areas of activity of the profession (EFPA, 2018). In the same way, the Portuguese Psychologists Order (OPP, 2015, 2016) adopts the same areas as performance and expertise areas.

In view of the configuration of the activity areas of the Psychology profession in Portugal, it is possible to understand that the students who participated in the research probably understand the Clinical and Health areas as belonging to a single major area of activity, represented in the EIAPsi evaluation as the Clinical and Health factor. Another complementary data for the evidence of this factor's validity can be noted by the higher average obtained in comparison with the others, indicating the students' continuous preference for the Clinical area (Ambiel \& Martins, 2016; 2019; Campos et al., 1999; Ferreira et al., 2015; Magalhães et al., 2001). In contrast, other areas understood jointly by the OPP, such as Social and Organizations, were broken down in the responses of the research participants, thus forming separate factors in the evaluation of the EIAPsi.

Another relevant result in terms of evidence of validity for EIAPsi, consists of positive correlations, mostly of moderate and strong magnitudes, between the scale factors. An association between the factors was expected, since specific domains of psychologists' performance are assessed, with Psychology as a common area of knowledge for all. In addition, the values of the alpha and omega coefficients pointed to satisfactory levels of accuracy through internal consistency in all factors of the EIAPsi.

Similar to what happened in the studies by Bullock and Reardon (2008), Hurtado Rúa et al. (2019) and Wille and De Fruyt (2014), this research also found positive correlations between the areas of interest in Psychology and the Big Five dimensions, with negative correlations observed only with the Neuroticism factor. It is worth to highlight the positive and moderate correlations between Openness and the areas of Teaching and Research, Social and Psychodiagnosis.
Thus, the most curious, creative students, with a preference for unconventional activities (DeYoung, Quilty, Peterson, \& Gray, 2014), possibly perceive in these three areas a possibility of acting more dynamically in Psychology, being consistent with this personality trait.

Regarding the dimensions of the NEO-FFI, it was found that the averages of each dimension are close to the normative average of Portuguese higher education students (Pedroso-Lima et al., 2014), with differences whose effect size, measured by Cohen's $d$, ranged from 0.03 (Openness) to 0.20 (Agreeableness), all of them considered low and null (Cohen, 1992). Neuroticism was also noted as the lowest score and the dimensions Agreeableness and Conscientiousness as the most scored in this sample, similar to what was found in the normative sample.

The failure to verify different scores for Psychology students is an indication that there would not be an exclusive profile for the course, as verified by Espírito and Castro (2012). However, for Pedroso-Lima et al. (2014), subjects with a higher level already present higher traits of Openness to Experience and Conscientiousness, when compared to lower levels of education. This indicates that, more than a specific training area, the insertion in higher education itself would already be more frequent in subjects with a certain personality profile, as indicated in the model of Holland (1963) and Savickas (1995). This observation by PedrosoLima et al. (2014) would also be an explanation for the Openness factor to have presented more correlations with the areas of interest in Psychology.

Some limitations are identified in this study as the absence of 2nd year students of the Master's program in Psychology. As these students would be closer to obtain the title of psychologists, it is possible to understand that it is necessary to investigate the relationships between personality traits and interest in areas of Psychology to test the hypothesis that these data would remain proportional to the ones observed here. The factorial structure of the EIAPsi with 10 factors can be verified in a larger sample, with Psychology students and professionals, through a Confirmatory Factor Analysis, so as to verify if this is the best configuration for the instrument, besides verifying whether the factorial structure of the instrument remains the same when comparing undergraduate students with Master's degree students in Psychology, due to possible differences in the understanding of the professional activities represented in the items.

Although it was not the aim of this study, we consider that in future research, other variables could be included to verify evidence of convergent validity (such as other scales of interest) and divergent validity (for example, cognitive instruments). The development of predictive models to explain the areas of choice would also make it possible to develop career interventions focused on Psychology students.

This study was able to contribute with an instrument for the evaluation of the interests for areas of Psychology, with important evidences of transcultural validity and satisfactory accuracy. Besides providing a preliminary description of the profiles of Portuguese Psychology students, regarding their 
personality traits and interests in areas of Psychology, also verifying the relationship of these two constructs in this sample. We expect that the EIAPsi can be a useful tool for teachers and professional advisors who intend to promote the self-knowledge of Psychology students about areas within the profession, to assist them in the choice of the areas where they intend to do their internships and perform when graduated. However, it is noteworthy that other areas of training also allow several possibilities of action, such as medicine and law, which also require investigation.

\section{References}

Ambiel, R. A. M., \& Martins, G. H. (2016). Interesses profissionais expressos e inventariados de estudantes de psicologia: Implicações para a formação [Expressed and inventoried vocational interest of psychology students: Implications for training]. Psicologia: Ensino \& Formação, 7(1), 5-17. doi:10.21826/2179-5800201671517

Ambiel, R. A. M., \& Martins, G. H. (2019). Estudo psicométrico da Escala de Interesses por Áreas da Psicologia (EIAPsi) [Psychological study of the Interests by Areas of Psychology Scale (EIAPsi)]. Psico, 50(4), e-32840. doi:10.15448/1980-8623.2019.4.32840

Ambiel, R. A. M., \& Martins, G. H. (2020). Escala de Interesses por Áreas da Psicologia - versão portuguesa (EIAPsi-PT) [Interests by Areas Psychology Scale portuguese version (IAPS-PT)]. São Paulo, Brasil: Universidade São Francisco.

Bedin, L. M., Sarriera, J. C., \& Paradiso, A. C. (2013). Desenvolvimento de carreira em psicólogos: Tarefas evolutivas de estabelecimento [Career development of psychologists: Developmental tasks at the Establishment Stage]. Revista Brasileira de Orientação Profissional, 14(1), 87-98. Retrieved from http://pepsic.bvsalud.org/scielo.php?script=sci_ arttext\&pid=S1679-33902013000100009

Bueno, J. M. H., Lemos, C. G., \& Tomé, F. A. M. F. (2004). Interesses profissionais de um grupo de estudantes de psicologia e suas relações com inteligência e personalidade [Professional interests of a psychology undergraduate students and its relation with intelligence and personality]. Psicologia em Estudo, 9(2), 271-278. doi:10.1590/S1413-73722004000200013

Bullock, E. E., \& Reardon, R. C. (2008). Interest profile elevation, big five personality traits, and secondary constructs on the self-directed search: A replication and extension. Journal of Career Assessment, 16(3), 326-338. doi:10.1177/1069072708317379
Campos, L. F. L., Catão, E. C., \& Fujii, C. M. (1999). Inventário cientista-prático de orientação profissional em psicologia: Um estudo exploratório [Scientist-practioner inventory in professional counseling in psychology: An exploratory study]. Psicologia Escolar e Educacional, 3(2), 139-150. doi:10.1590/S1413-85571999000200004

Cohen, J. (1992). A power primer. Psychological Bulletin, 112(1). 155-159. doi: 10.1037/0033-2909.112.1.155

Decreto-Lei No. 42 (2005, 22 de fevereiro). Dispõe sobre a Declaração de Bolonha, acordo que contém como objectivo central o estabelecimento, até 2010, do espaço europeu de ensino superior, coerente, compatível, competitivo e atractivo para estudantes europeus e de países terceiros, espaço que promova a coesão europeia através do conhecimento, da mobilidade e da empregabilidade dos seus diplomados [Provides for the Bologna Declaration, an agreement that has as its central or established objective, until 2010, the European space of higher education, coherent, compatible, competitive and attractive for European and third country students, a space that promotes an initial cohesion with knowledge , mobility and employability of its graduates]. Diário da República, série 1. Retrieved from https://dre.pt/ application/file/606224

DeYoung, C. G., Quilty, L. C., Peterson, J. B., \& Gray, J. R. (2014). Openness to experience, intellect, and cognitive ability. Journal of Personality Assessment, 96(1), 46-52. doi:10.1080/00223891.2013.806327

Espírito,A.C.O., \& Castro, P.F.(2012). Avaliação da tipologia psicológica observada em uma amostra de estudantes de um curso de psicologia [Assessment of the psychological typology observed in a sample of students from a psychology undergraduate program]. Gerais: Revista Interinstitucional de Psicologia, 5(1), 86-107. Retrieved from http://pepsic.bvsalud.org/scielo.php?script=sci arttext\&pid $=$ S1983-82202012000100007

European Federation of Psychologists' Associations. (2018). EuroPsy-The European certificate in psychology. Retrieved from https://www.europsy.eu/europsyregister\#: : text=The $\% 20$ main $\% 20$ areas $\% 20$ of $\% 20$ practice, 5 .

Ferreira, A. I., Rodrigues, R. I., \& Ferreira, P. C. (2015). Career interests of students in psychology specialties degrees: Psychometric evidence and correlations with the RIASEC dimensions. International Journal for Educational and Vocational Guidance, 16(1), 91-111. doi:10.1007/s10775-015-9289-3

Holland, J. L. (1963). Explorations of a theory of vocational choice and achievement: II. A four-year prediction study. Psychological Reports, 12(2), 547-594. doi:10.2466/ pr0.1963.12.2.547 
Holland, J. L. (1997). Making vocational choices: A theory of vocational personalities and work environments (3rd ed.). Odessa, FL: Psychological Assessment Resources.

Hu, L.-T., \& Bentler, P. M. (1999). Cutoff criteria for fit indexes in covariance structure analysis: Conventional criteria versus new alternatives. Structural Equation Modeling: A Multidisciplinary Journal, 6(1), 1-55. doi:10.1080/10705519909540118

Hurtado Rúa, S. M., Stead, G. B., \& Poklar, A. E. (2019). Fivefactor personality traits and RIASEC interest types: A multivariate meta-analysis. Journal of Career Assessment, 27(3), 527-543. doi:10.1177/1069072718780447

Lamas, K. C. A. (2017). Conceito e relevância dos interesses profissionais no desenvolvimento de carreira: Estudo teórico [Concept and relevance of vocational interests in career development: A theoretical study]. Temas em Psicologia, 25(2), 703-717. doi:10.9788/TP2017.2-16Pt

Lent, R. W., Brown, S. D., \& Hackett, G. (1994). Toward a unifying social cognitive theory of career and academic interest, choice, and performance. Journal of Vocational Behavior, 45(1), 79-122. doi:10.1006/jvbe.1994.1027

Lima, M. P., \& Simões, A. (2000). NEO PI-R: Manual profissional [NEO PI-R: Professional manual]. Lisboa, Portugal: CEGOC.

Low, K. S. D., \& Rounds, J. (2007). Interest change and continuity from early adolescence to middle adulthood. International Journal for Educational and Vocational Guidance, 7(1), 23-36. doi:10.1007/s10775-006-9110-4

Magalhães, E., Salgueira, A., Gonzalez, A.-J., Costa, J. J., Costa, M. J., Costa, P., \& Lima, M. P. (2014). NEOFFI: Psychometric properties of a short personality inventory in a Portuguese context. Psicologia: Reflexão e Crítica, 27(4), 642-657. doi:10.1590/16787153.201427405

Magalhães, M., Straliotto, M., Keller, M., \& Gomes, W. B. (2001). Eu quero ajudar as pessoas: A escolha vocacional da psicologia [I want to help people: The vocational choice of psychology]. Psicologia: Ciência e Profissão, 21(2), 10-27. doi:10.1590/S1414-98932001000200003

Mendes, S. A., Abreu-Lima, I., \& Almeida, L. S. (2015). Psicólogos escolares em Portugal: Perfil e necessidades de formação [School psychologists in Portugal: Training profile and educational needs]. Estudos de Psicologia (Campinas), 32(3), 405-416. doi:10.1590/0103-166X2015000300006

Ordem dos Psicólogos Portugueses. (2015). Projeto eu quero ser psicólogo [Project I want to be a psychologist]. Retrieved from http://euqueroserpsicologo.pt/p-projecto
Ordem dos Psicólogos Portugueses. (2016). Regulamento No. 107-A. Regulamento geral de especialidades profissionais da ordem dos psicólogos portugueses [General regulation of professional specialties of the order of Portuguese psychologists]. Diário da República, série 2. Retrieved from http://direitodamedicina.sanchoeassociados. com/arquivo/regulamento-n-o-107-a2016-ordemdos-psicologos-portugueses-por-deliberacao-daassembleia-de-representantes-da-ordem-dos-psicologosportugueses-de-5-de-junho-de-2015-foi-aprovado/

Pasquali, L. (2003). Psicometria: Teoria dos testes na psicologia e na educação [Psychometrics: Test theory in psychology and education]. Petrópolis, RJ: Vozes.

Pedroso-Lima, M., Magalhães, E., Salgueira, A., Gonzalez, A. J., Costa, J. J., Costa, M. J., \& Costa, P. (2014). A versão portuguesa do NEO-FFI: Caracterização em função da idade, género e escolaridade [The Portuguese version of the NEO-FFI: Age, gender and education characterization]. Psicologia, 28(2), 1-10. Retrieved from http://www.scielo.mec.pt/scielo.php?script=sci_ arttext\&pid=S087420492014000200001

Rodrigues, R. I., Ferreira, A. I., \& Bártolo-Ribeiro, R. (2013). Construção e desenvolvimento de um questionário de interesses para a psicologia [Construction and development of an interests questionnaire for Psychology]. Revista Iberoamericana de Diagnóstico y Evaluación/e Avaliação Psicológica, 36(2), 99-116. Retrieved from https://www. aidep.org/sites/default/files/articles/R36/Art.\%25205.pdf

Rounds, J., \& Su, R. (2014). The nature and power of interests. Current Directions in Psychological Science, 23(2), 98-103. doi:10.1177/0963721414522812

Savickas, M. L. (1995). Examining the personal meaning of inventoried interests during career counseling. Journal of Career Assessment, 3(2), 188-201. doi:10.1177/106907279500300206

Shimada, M., Melo-Silva, L. L., \& Taveira, M. C. (2016). Interesses profissionais e personalidade: Estudo correlacional entre o BBT-Br e a BFP [Vocational interests and personality: A correlational study between BBT-Br and BFP]. Revista Brasileira de Orientação Profissional, 17(1), 31-42. Retrieved from http://pepsic.bvsalud.org/scielo. php?script=sci_arttext\&pid=S1679-33902016000100005

Wille, B., \& De Fruyt, F. (2014). Vocations as a source of identity: Reciprocal relations between Big Five personality traits and RIASEC characteristics over 15 years. Journal of Applied Psychology, 99(2), 262-281. doi:10.1037/a0034917

Yamamoto, O. H., \& Costa, A. L. F. (2010). Escritos sobre a profissão de psicólogo no Brasil [Writings about the profession of psychologist in Brazil]. Natal, RN: EDUFRN. 
Rodolfo Augusto Matteo Ambiel is a Professor of the Universidade São Francisco, Campinas-SP, Brazil.

Gustavo Henrique Martins is a Ph.D. candidate of the Universidade São Francisco, Campinas-SP, Brazil.

Maria do Céu Taveira is a Professor of the Universidade do Minho, Braga-Portugal.

Ana Carolina Zuanazzi is a Ph.D. of the Universidade São Francisco, Campinas-SP, Brazil.

Jucimara Zacarias Martins is a Ph.D. of the Universidade São Francisco, Campinas-SP, Brazil.

Airton Antonio Cicchetto is a Ph.D. candidate of the Universidade São Francisco, Campinas-SP, Brazil.

\section{Authors' contributions:}

The authors Rodolfo Augusto Matteo Ambiel and Gustavo Henrique Martins made substantial contributions to the conception and design of this study, to the analysis and interpretation of data and to the manuscript revision and approval of the final version. The author Maria do Céu Taveira made substantial contributions to the conception and design of this study and to the manuscript revision and approval of the final version. The authors Ana Carolina Zuanazzi and Airton Antonio Cicchetto made substantial contributions to the manuscript revision and approval of the final version. The author Jucimara Zacarias Martins made substantial contributions to the analysis and interpretation of data and to the manuscript revision and approval of the final version.

Received: Sep. 28, 2018

1st Revision: Dec. 11, 2018

2nd Revision: Feb. 18, 2019

Approved: Mar. 07, 2019

How to cite this article:

Ambiel, R.A. M., Martins, G. H., Taveira, M. C., Zuanazzi, A. C., Martins, J.Z., \& Cicchetto,A.A.(2020). Psychometric study of the scale of interests by areas of psychology portuguese version. Paidéia (Ribeirão Preto), 30, e3029.doi:https://doi.org/10.1590/1982-4327e3029 


\section{Appendix}

\section{Escala de Interesses por Áreas da Psicologia - versão portuguesa (EIAPsi-PT)}

Rodolfo Augusto Matteo Ambiel, Gustavo Henrique Martins e Maria do Céu Taveira (2020)

A seguir, encontrará listadas atividades que os psicólogos podem exercer profissionalmente. Por favor, leia atentamente cada uma e marque o número que corresponde ao seu grau de interesse por essa mesma atividade (quanto gosta ou gostaria de exercer cada atividade), de acordo com a seguinte escala:

\begin{tabular}{|c|c|c|c|c|c|c|c|c|}
\hline $\begin{array}{c}\text { Detesto/detestaria exercer } \\
\text { essa atividade }\end{array}$ & $\begin{array}{c}\text { Não gosto/não gostaria de } \\
\text { exercer essa atividade }\end{array}$ & $\begin{array}{l}\text { Imparcial/neutro em } \\
\text { relação a essa atividade }\end{array}$ & \multicolumn{2}{|c|}{$\begin{array}{c}\text { Gosto/gostaria de exercer } \\
\text { essa atividade }\end{array}$} & \multicolumn{4}{|c|}{$\begin{array}{c}\text { Adoro/adoraria exercer } \\
\text { essa atividade }\end{array}$} \\
\hline 1 & 2 & 3 & \multicolumn{2}{|l|}{4} & \multicolumn{4}{|c|}{5} \\
\hline \multicolumn{4}{|c|}{ Publicar artigos científicos } & 1 & 2 & 3 & 4 & 5 \\
\hline \multicolumn{4}{|c|}{ 2. Conhecer e aplicar diversos testes psicológicos } & 1 & 2 & 3 & 4 & 5 \\
\hline \multicolumn{4}{|c|}{ 3. Atuar com indivíduos em situação de processos judiciais } & 1 & 2 & 3 & 4 & 5 \\
\hline \multicolumn{4}{|c|}{ 4. Compreender as relações do funcionamento cerebral com o comportamento } & 1 & 2 & 3 & 4 & 5 \\
\hline \multicolumn{4}{|c|}{ 5. Elaborar relatórios sobre o funcionamento mental dos indivíduos em processos judiciais } & 1 & 2 & 3 & 4 & 5 \\
\hline \multicolumn{4}{|c|}{ 6. $\quad$ Propor projetos de pesquisa inovadores para responder a questões da psicologia } & 1 & 2 & 3 & 4 & 5 \\
\hline \multicolumn{4}{|c|}{ 7. Realizar atendimentos psicoterapêuticos em consultórios ou clínicas particulares } & 1 & 2 & 3 & 4 & 5 \\
\hline \multicolumn{4}{|c|}{ 8. $\quad$ Auxiliar nos processos de ensino-aprendizagem } & 1 & 2 & 3 & 4 & 5 \\
\hline \multicolumn{4}{|c|}{ 9. Colaborar na formulação de políticas penais } & 1 & 2 & 3 & 4 & 5 \\
\hline \multicolumn{4}{|c|}{ 10. Atender famílias com pacientes em estado terminal, auxiliando no processo de aceitação } & 1 & 2 & 3 & 4 & 5 \\
\hline \multicolumn{4}{|c|}{ 11. Desenvolver jogos e atividades para avaliação, prevenção e reabilitação neuropsicológica } & 1 & 2 & 3 & 4 & 5 \\
\hline \multicolumn{4}{|c|}{ 12. Trabalhar em ONGs garantindo suporte psicológico aos seus destinatários } & 1 & 2 & 3 & 4 & 5 \\
\hline \multicolumn{4}{|c|}{ 13. Escrever relatos e artigos científicos } & 1 & 2 & 3 & 4 & 5 \\
\hline \multicolumn{4}{|c|}{ 14. Fazer a avaliação de detidos que estão em liberdade condicional } & 1 & 2 & 3 & 4 & 5 \\
\hline \multicolumn{4}{|c|}{ 15. Realizar avaliações para se chegar a um psicodiagnóstico } & 1 & 2 & 3 & 4 & 5 \\
\hline \multicolumn{4}{|c|}{ 16. Intervir em situações de conflitos entre funcionários } & 1 & 2 & 3 & 4 & 5 \\
\hline \multicolumn{4}{|c|}{ 17. Auxiliar na decisão sobre o tratamento médico para pacientes neurológicos } & 1 & 2 & 3 & 4 & 5 \\
\hline \multicolumn{4}{|c|}{ 18. Atuar no apoio psicológico das famílias dos detidos } & 1 & 2 & 3 & 4 & 5 \\
\hline \multicolumn{4}{|c|}{ 19. Trabalhar na integração família-comunidade-escola } & 1 & 2 & 3 & 4 & 5 \\
\hline 20. Realizar pesquisas no & âmbito social e comunitário & & & 1 & 2 & 3 & 4 & 5 \\
\hline 21. Ajudar na integração & da população em atividades & isicas & & 1 & 2 & 3 & 4 & 5 \\
\hline 22. Facilitar o desenvolvi & mento e integração de alunos & no âmbito escolar & & 1 & 2 & 3 & 4 & 5 \\
\hline 23. Promover a reabilitaça & to psicossocial de indivíduos & com depressão & & 1 & 2 & 3 & 4 & 5 \\
\hline 24. Promover atividades c & ue os detidos possam realiz & r em estabelecimentos pen & & 1 & 2 & 3 & 4 & 5 \\
\hline 25. Atuar junto a paciente & s terminais hospitalizados & & & 1 & 2 & 3 & 4 & 5 \\
\hline 26. Atualizar-se constante & mente em relação à literatur & científica & & 1 & 2 & 3 & 4 & 5 \\
\hline 27. Supervisionar outros 1 & sicólogos clínicos & & & 1 & 2 & 3 & 4 & 5 \\
\hline 28. Ajudar pessoas que so & freram de algum tipo de aci & ente & & 1 & 2 & 3 & 4 & 5 \\
\hline 29. Auxiliar no bem-estar & do trabalhador & & & 1 & 2 & 3 & 4 & 5 \\
\hline $\begin{array}{l}\text { 30. Orientar pais ou respo } \\
\text { de desenvolvimento d }\end{array}$ & $\begin{array}{l}\text { nsáveis quanto a escolha da } \\
\text { a criança }\end{array}$ & nodalidade desportiva e às & implicações no ciclo & 1 & 2 & 3 & 4 & 5 \\
\hline 31. Capacitar-se para a fo & rmação ou o ensino universi & ário & & 1 & 2 & 3 & 4 & 5 \\
\hline $\begin{array}{l}\text { 32. Participar em equipas } \\
\text { segurança rodoviária }\end{array}$ & multiprofissionais viradas $p$ & ra o planeamento e realiza & o de políticas de & 1 & 2 & 3 & 4 & 5 \\
\hline 33. Realizar atendimentos & psicoterapêuticos com indi & íduos, casais, famílias e gr & upos & 1 & 2 & 3 & 4 & 5 \\
\hline 34. Atuar atendendo grup & os em situação de vulnerabil & dade, em centros comunitá & rios & 1 & 2 & 3 & 4 & 5 \\
\hline $\begin{array}{l}\text { 35. Colaborar para a com } \\
\text { desportivos }\end{array}$ & oreensão e transformação da & relações inter e intrapesso & ais em ambientes & 1 & 2 & 3 & 4 & 5 \\
\hline 36. Elaborar problemas de & pesquisa e hipóteses & & & 1 & 2 & 3 & 4 & 5 \\
\hline 37. Trabalhar em empresa & & & & 1 & 2 & 3 & 4 & 5 \\
\hline 38. Analisar os diversos $\mathrm{s}$ & egmentos do sistema educac & onal & & 1 & 2 & 3 & 4 & 5 \\
\hline 39. Realizar atendimentos & com o intuito de preparar $u$ & $\mathrm{n}$ atleta para o desempenho & da atividade & 1 & 2 & 3 & 4 & 5 \\
\hline 40. Intervir nos fenómeno & s psicológicos do indivíduo & & & 1 & 2 & 3 & 4 & 5 \\
\hline 41. Avaliar a eficiência de & programas educacionais a par & $\mathrm{r}$ de testes psicológicos e in & trumentos adequados & 1 & 2 & 3 & 4 & 5 \\
\hline 42. Assessorar ONGs e cc & operativas de trabalho & & & 1 & 2 & 3 & 4 & 5 \\
\hline
\end{tabular}




\begin{tabular}{|c|c|c|c|c|c|}
\hline 43. Ministrar aulas sobre conteúdos específicos & 1 & 2 & 3 & 4 & 5 \\
\hline 44. Comunicar resultados de avaliações & 1 & 2 & 3 & 4 & 5 \\
\hline 45. Atender pessoas que passaram por um grande desastre & 1 & 2 & 3 & 4 & 5 \\
\hline 46. Aplicar instrumentos para determinação de perfil, individual e coletivo, para a prática desportiva & 1 & 2 & 3 & 4 & 5 \\
\hline 47. Elaborar um plano de tratamento para reabilitação neuropsicológica do paciente & 1 & 2 & 3 & 4 & 5 \\
\hline 48. Analisar os diferentes fatores envolvidos em acidentes de trânsito & 1 & 2 & 3 & 4 & 5 \\
\hline 49. Orientar trabalhos de alunos de iniciação científica, mestrado e doutoramento & 1 & 2 & 3 & 4 & 5 \\
\hline 50. Responsabilizar-se em melhorar as condições de trabalho na organização & 1 & 2 & 3 & 4 & 5 \\
\hline 51. Atender a pacientes/clientes com base numa abordagem teórica específica & 1 & 2 & 3 & 4 & 5 \\
\hline 52. Envolver-se em pesquisas que ampliam o conhecimento psicológico aplicado ao direito & 1 & 2 & 3 & 4 & 5 \\
\hline 53. Saber selecionar adequadamente instrumentos para diferentes situações de avaliação & 1 & 2 & 3 & 4 & 5 \\
\hline 54. Realizar avaliação das funções neuropsicológicas & 1 & 2 & 3 & 4 & 5 \\
\hline 55. Orientar a aplicação de programas específicos de ensino para indivíduos com necessidades especiais & 1 & 2 & 3 & 4 & 5 \\
\hline 56. Realizar análises estatísticas & 1 & 2 & 3 & 4 & 5 \\
\hline 57. Atuar em dispositivos de saúde pública & 1 & 2 & 3 & 4 & 5 \\
\hline 58. Trabalhar com crianças com dificuldade e/ou atrasos no desenvolvimento global & 1 & 2 & 3 & 4 & 5 \\
\hline 59. Participar no processo de despedimento de funcionários da empresa & 1 & 2 & 3 & 4 & 5 \\
\hline 60. Ajudar atletas, técnicos e comissões técnicas a alcançarem um nível ótimo de saúde mental & 1 & 2 & 3 & 4 & 5 \\
\hline 61. Planear processos de avaliação em diversos contextos de atuação & 1 & 2 & 3 & 4 & 5 \\
\hline 62. Utilizar diversas técnicas para melhorar a eficiência das práticas psicoterapêuticas & 1 & 2 & 3 & 4 & 5 \\
\hline 63. Atuar como perito/a em exames de habilitação, reabilitação ou readaptação profissional do motorista & 1 & 2 & 3 & 4 & 5 \\
\hline 64. Realizar trabalhos de investigação clínica, utilizando testes e exercícios neuropsicológicos & 1 & 2 & 3 & 4 & 5 \\
\hline 65. Participar de juris de arguição de mestrado e doutoramento & 1 & 2 & 3 & 4 & 5 \\
\hline 66. Planear, avaliar e executar políticas públicas e programas comunitários & 1 & 2 & 3 & 4 & 5 \\
\hline 67. Auxiliar na preparação de pacientes para entrada, permanência e alta hospitalar & 1 & 2 & 3 & 4 & 5 \\
\hline 68. Compreender o significado subjetivo atribuído pelos funcionários ao trabalho exercido & 1 & 2 & 3 & 4 & 5 \\
\hline 69. Avaliar capacidades, habilidades e aptidões de candidatos à carteira de motorista & 1 & 2 & 3 & 4 & 5 \\
\hline 70. Colaborar para a adesão e participação da população em geral em programas de atividades físicas & 1 & 2 & 3 & 4 & 5 \\
\hline 71. Trabalhar com as relações entre os sujeitos existentes no ambiente de trabalho & 1 & 2 & 3 & 4 & 5 \\
\hline 72. Mediar as intervenções de equipas multiprofissionais nos contextos comunitários & 1 & 2 & 3 & 4 & 5 \\
\hline 73. Dar pareceres de manuscritos para as revistas científicas da área & 1 & 2 & 3 & 4 & 5 \\
\hline 74. Assistir o paciente, a sua família e a equipa de saúde, numa unidade de saúde & 1 & 2 & 3 & 4 & 5 \\
\hline 75. Analisar e intervir no clima educacional & 1 & 2 & 3 & 4 & 5 \\
\hline 76. Facilitar as relações entre pessoas e organizações, contribuindo para o desenvolvimento de ambas & 1 & 2 & 3 & 4 & 5 \\
\hline 77. Possibilitar a tomada de decisão a partir de avaliações & 1 & 2 & 3 & 4 & 5 \\
\hline 78. Privilegiar os processos grupais nas avaliações e intervenções & 1 & 2 & 3 & 4 & 5 \\
\hline 79. Atuar preventivamente nas creches e escolas & 1 & 2 & 3 & 4 & 5 \\
\hline 80. Elaborar e implantar programas de saúde, educação e segurança do trânsito & 1 & 2 & 3 & 4 & 5 \\
\hline $\begin{array}{l}\text { 81. Atuar em centros e postos de saúde na comunidade, hospitais, clínicas psiquiátricas ou de } \\
\text { atendimento à saúde mental }\end{array}$ & 1 & 2 & 3 & 4 & 5 \\
\hline 82. Selecionar funcionários para um novo emprego & 1 & 2 & 3 & 4 & 5 \\
\hline 83. Identificar as representações sociais que medeiam as relações dos indivíduos com os seus ambientes & 1 & 2 & 3 & 4 & 5 \\
\hline $\begin{array}{l}\text { 84. Desenvolver ações para a melhoria das capacidades psíquicas individuais com vista a otimizar o } \\
\text { rendimento de atletas de alta competição }\end{array}$ & 1 & 2 & 3 & 4 & 5 \\
\hline 85. Realizar coletas de dados utilizando diferentes técnicas & 1 & 2 & 3 & 4 & 5 \\
\hline
\end{tabular}

